\title{
Crude extract and fractions from Eugenia uniflora Linn leaves showed anti- inflammatory, antioxidant, and antibacterial activities
}

Tamires Rocha Falcão ${ }^{1}$, Aurigena Antunes de Araújo ${ }^{1 *}$, Luiz Alberto Lira Soares², Rhayanne Thaís de Moraes Ramos², Isabelle Cristinne Ferraz Bezerra², Magda Rhayanny Assunção Ferreira², Manoel André de Souza Neto ${ }^{3}$, Maria Celeste Nunes Melo $^{4}$, Raimundo Fernandes de Araújo $\mathrm{Jr}^{5}$, Andreza Conceição Véras de Aguiar Guerra ${ }^{5}$, Juliana Silva de Medeiros ${ }^{1,5}$ and Gerlane Coelho Bernardo Guerra ${ }^{1}$

\begin{abstract}
Background: This study showed phytochemical composition and evaluates the anti-inflammatory, and analgesic activities of crude extract (CE) and fractions from E. uniflora Linn leaves.

Methods: Polyphenols present in crude extract (CE), in aqueous fraction (AqF), and ethyl acetate (EAF) treated fractions from E. uniflora Linn leaves were shown by chromatographic analysis in order to conduct a phytochemical characterization. Antibacterial activity was evaluated based on minimum inhibitory concentrations (MICs) determined using the agar dilution method. Doses of 50, 100, and $200 \mathrm{mg} / \mathrm{kg}$ of the CE and fractions were applied for conducting in vivo models (male Swiss mice, 8-10 weeks old). The peritonitis experimental model was induced by carrageenan following of Myeloperoxidase activity (MPO), Total glutathione and malondialdehyde (MDA), IL-1 $\beta$ and TNF-a levels by spectroscopic UVNIS analysis. Antinociceptive activity was evaluated based on an abdominal writhing model and hot plate test. The results were statistically evaluated using one-way analysis of variance (ANOVA), followed by Bonferroni's post-hoc test. The level of statistical significance was $p<0.05$.
\end{abstract}

Results: High-performance liquid chromatography with photodiode array detection (HPLC-DAD) detected varying concentrations of gallic acid, ellagic acid, and myricitrin in the CE and fractions obtained from E. uniflora Linn leaves $(0.05-0.87 \% \mathrm{w} / \mathrm{w}, 0.20-0.32 \% \mathrm{w} / \mathrm{W}$, and $1.71-6.56 \% \mathrm{w} / \mathrm{W}$, respectively). In general, the CE had lower MIC values than the fractions, including the lowest MIC against the MRSA strain. The CE and AqF also significantly reduced leukocyte migration and MPO activity ( $p<0.05)$. In addition, AgF significantly reduced IL-1 $\beta$ and TNF-a levels $(p<0.05)$. Furthermore, the CE and fractions exhibited an antioxidant effect $(p<0.05)$ and peripheral analgesic activity $(p<0.05)$.

Conclusions: The CE and fractions from the studied E. uniflora Linn leaves exhibited antibacterial, anti-inflammatory, antioxidant, and analgesic activity in the performed assays.

Keywords: Eugenia uniflora Linn, Anti-inflammatory, Antinociceptive, Oxidative stress, Antibacterial

\footnotetext{
* Correspondence: aurigena@ufrnet.br

1 Department of Biophysics and Pharmacology, UFRN, Av. Senador Salgado

Filho, S/N, Campus Universitário, Lagoa Nova, Natal, RN 59072-970, Brazil

Full list of author information is available at the end of the article
}

(c) The Author(s). 2018 Open Access This article is distributed under the terms of the Creative Commons Attribution 4.0 International License (http://creativecommons.org/licenses/by/4.0/), which permits unrestricted use, distribution, and reproduction in any medium, provided you give appropriate credit to the original author(s) and the source, provide a link to the Creative Commons license, and indicate if changes were made. The Creative Commons Public Domain Dedication waiver (http://creativecommons.org/publicdomain/zero/1.0/) applies to the data made available in this article, unless otherwise stated. 


\section{Background}

Eugenia uniflora Linn (Myrtaceae) is a species that is native to Brazil and is commonly known as pitanga (Surinam cherry) or pitangueira (Brazilian cherry). It is present as a shrub in the midwest, northeast, southeast, and southern regions of Brazil [1, 2]. In Brazilian folk medicine, the leaves of E. uniflora Linn are used in infusions, decoctions, and alcoholic extracts for treating diarrhea, stomachache, colic, intestinal infection, verminosis, fever, flu, cough, bronchitis, anxiety, high blood pressure, and diabetes $[3,4]$. Other ethnobotanical studies which did not specify the vegetal part employed have reported the use of this species for treating fever, flu, throat inflammation, dental inflammation, headache, high arterial pressure, and high cholesterol [5].

According to preliminary phytochemical analyses that have been performed, E. uniflora Linn leaves contain alkaloids, triterpenes, tannins, flavonoids, and antraquinones [6]. In more detailed studies, hydrolysable tannins (eugiflorins D1 and D2, camptothin A, oenothein B, gemin $\mathrm{D}$, hippomanin A), flavonoids (afzelin, desmanthin1 , myricitrin, quercitrin, and glycosides of myricetin and quercetin), and terpenoids ( $\beta$-sitosterol, betulinic acid, and centelloside $C$ ) have been identified, and isolated in some cases [7].

While many studies have investigated E. uniflora, few studies have examined a possible correlation between the phytochemical composition of this dicotyledonous plant and its biological activities. A study by Schumacher et al. (2015) showed that E. uniflora Linn leaves reduce the inflammatory infiltrate index in pancreatic islets, maintaining serum insulin levels and hepatic glutathione, and reducing serum lipid peroxidation, as well as reducing the risk for diabetes in non-obese diabetic (NOD) mice [8]. Flavonoid-rich fraction (HE-Bu) obtained from E. uniflora leaves decreased TNF- $\alpha$ and IL-1 $\beta$ serum levels, and markedly decreased iNOS and COX-2 protein expression by ileum cells in an in vivo sepsis experimental model [7]. Leaf essential oil and isolated terpenoids from Eugenia uniflora Linn presented an analgesic effect in vivo using the mouse abdominal constriction test induced by acetic acid and hot plate test [2].

The aim of the present study was to conduct a phytochemical characterization of E. uniflora Linn leaves, while also evaluating the cytotoxicity, antibacterial, antiinflammatory, and analgesic activity of a crude extract (CE) and prepared fractions from E. uniflora Linn leaves.

\section{Methods}

\section{Herbal material}

A sample of E. uniflora Linn leaves was collected in the city of Ipojuca (Pernambuco State, Brazil). The species was identified in a herbarium by Dr. Rita de Cássia Pereira and the voucher specimens were deposited at the
Agronomy Institute of Pernambuco (IPA), under number 89989. The plant names were verified by http://www.theplantlist.org/.

\section{Obtaining CE and enriched fractions of E. uniflora Linn leaves}

E. uniflora Linn leaves (50 g) were dried, ground, and then extracted $(10 \%, w / v)$ with acetone: water $(7: 3, v / v)$ by turbo extraction for $20 \mathrm{~min}$ at $5 \mathrm{~min}$ intervals each with $30 \mathrm{~s}$ cycles. The solution was then concentrated under reduced pressure (RV10 Basic, IKA $\left.{ }^{\odot}\right)$. The resulting residue was frozen $\left(-80{ }^{\circ} \mathrm{C}, 3 \mathrm{~d}\right)$ and then lyophilized (Model L101, Liotop ${ }^{\oplus}$ ) to yield CE (with a yield of $10 \mathrm{~g})$. Approximately $10 \mathrm{~g}$ of CE were reconstituted in water $(100 \mathrm{~mL})$. The resulting aqueous fraction was partitioned twelve more times with $10 \mathrm{~mL}$ ethyl acetate. These aqueous ( $4 \mathrm{~g}$ yield) and ethyl acetate ( 2 g yield) fractions (hereafter referred to as AqF and EAF) were concentrated, frozen, and lyophilized.

\section{Preparation of solutions for analysis by high-performance liquid chromatography with photodiode array detection (HPLC-DAD)}

Fifty $\mathrm{mg}$ of the $\mathrm{CE}$ and fractions were weighed and transferred to $25 \mathrm{~mL}$ volumetric flasks. Following the addition of $20 \mathrm{~mL}$ of ultrapure water (Elga ${ }^{\oplus}$ ) to each flask, the flasks were then transferred to an ultrasonic bath (Ultracleaner, Unique ${ }^{\circledR}$ ) to achieve complete dissolution. After $15 \mathrm{~min}$, the $\mathrm{CE}$ and fractions were each diluted to $1 \mathrm{mg} / \mathrm{mL}$ with ultrapure water. Gallic acid (96\% purity, Sigma ${ }^{\oplus}$ ) [8], ellagic acid from tree bark (95\% purity, Sigma ${ }^{\oplus}$ [8], and myricitrin (99\% purity, Sigma ${ }^{\oplus}$ [7] were used as reference standards. The $\mathrm{CE}$, fractions, and standards were filtered through a polyvinylidene difluoride (PVDF) $0.45 \mu \mathrm{m}$ membrane (Macherey-Nagel ${ }^{\oplus}$ ) prior to HPLC analysis. The HPLC analyses were performed in triplicate.

\section{Chromatographic conditions}

A Thermo Scientific system (Ultimate 3000 Thermo Fisher Scientific ${ }^{\oplus}$ ) equipped with a DAD (Thermo Fisher Scientific ${ }^{\odot}$ ), binary pump (HPG-3x00RS, Thermo Fisher Scientific ${ }^{\odot}$, degasser and an autosampler equipped with a $20 \mu \mathrm{L}$ loop (ACC-3000, Thermo Fisher Scientific ${ }^{\circledR}$ ) was used to perform the HPLC analyses. Chromeleon 6.8 software $\left(\right.$ Dionex $^{\odot}$ ) was used for data acquisition and data processing.

Chromatographic separation was performed with a $\mathrm{C}_{18}$ column $(250 \mathrm{~mm} \times 4.6 \mathrm{~mm}$ inner diameter, $5 \mu \mathrm{m}$; Dionex ${ }^{\oplus}$ ) that was protected by a guard column made of the same material (Phenomenex ${ }^{\odot}$ ). A gradient elution was achieved by varying the proportion of solvent $\mathrm{B}$ (methanol with $0.05 \%, v / \mathrm{v}$, trifluoracetic acid) to solvent $\mathrm{A}$ (water with $0.05 \%, \mathrm{v} / \mathrm{v}$, trifluoracetic acid) at a flow rate 
of $0.8 \mathrm{~mL} / \mathrm{min}$, according to the following gradient program: $10-25 \%$ B (10 min), $25-40 \%$ B (5 min), 4070\% B (10 min), 75\% B (5 min), and 75-10\% B (1 min). Separations were carried out in a column oven at a temperature of $23 \pm 2{ }^{\circ} \mathrm{C}$. Wavelengths of $254 \mathrm{~nm}$, $270 \mathrm{~nm}$, and $350 \mathrm{~nm}$ were used for detecting ellagic acid, gallic acid, and myricitrin, respectively, according to the maximum absorption measured by DAD.

\section{In vitro study}

\section{Antibacterial activity}

Antibacterial activity of the CE and fractions was tested against medically important gram-positive and gramnegative bacteria available from the Medical Bacteriology Laboratory, UFRN, Brazil. The gram-positive group included: Staphylococcus aureus ATCC 25923, Staphylococcus epidermidis INCQS 00016, Enterococcus faecalis ATCC 29212, and a methicillin resistant Staphylocuccus aureus (MRSA) strain [representative of the Brazilian epidemic clone [9]. The gram-negative group included: Escherichia coli ATCC 25922, Salmonella enteritidis INCQS 00258, and Pseudomonas aeruginosa ATCC. All of these bacteria were previously maintained at $-20{ }^{\circ} \mathrm{C}$ and were reactivated on Brain Heart Infusion Broth (BHI, HiMedia ${ }^{\circ}$, India) at $37{ }^{\circ} \mathrm{C}$ for $24 \mathrm{~h}$. Bacterial suspensions were standardised to a turbidity equivalent to the 0.5 McFarland standard tube before the antibacterial testing was performed.

Minimum inhibitory concentrations (MICs) were determined by the agar dilution method according to the Clinical and Laboratory Standards Institute M07-A9 document [10], with some modifications. First, stock DMSO aqueous solutions $(50 \%, v / v)$ of the CE and fractions $(25 \mathrm{mg} / \mathrm{mL})$ were prepared and subsequently filtered through sterile $0.22 \mu \mathrm{m}$ pore syringe filters (Kasvi ${ }^{\circ}$, Brazil). Serial volumes of these stock solutions were then transferred to sterile $15 \mathrm{ml}$ tubes containing MuellerHinton agar (MHA, HiMedia ${ }^{\circ}$, India) liquefied at $50{ }^{\circ} \mathrm{C}$. The solutions were subsequently homogenized and transferred to sterile Petri dishes (6 mm diameter). The concentration of these samples ranged from $0.039 \mathrm{mg} /$ $\mathrm{mL}$ to $2.5 \mathrm{mg} / \mathrm{mL}$, with a final DMSO concentration at the highest sample concentration being $(5 \% \mathrm{v} / \mathrm{v})$. Next, the standardised bacterial suspensions were diluted by 1:10 and $2 \mu \mathrm{L}$ of each diluted suspension was transferred to media containing the $\mathrm{CE}$ or fractions and incubated at $37^{\circ} \mathrm{C}$ for $24 \mathrm{~h}$. In addition, a growth control (MHA + innoculum), a solvent control (MHA containing 5\% DMSO), and a sterility control (MHA) were incubated at $37{ }^{\circ} \mathrm{C}$ for $24 \mathrm{~h}$. Cephalothin, gentamicin and vancomycin (Sigma, St. Louis, MO, USA) were employed as reference antibiotics. The MIC was considered to be the lowest extract or fraction concentration that prevented the visible growth of bacteria.

\section{In vivo studies}

This study was carried out in strict accordance with the recommendations in the Guide for the Care and Use of Laboratory Animals of the National Institutes of Health. The protocol was approved by the Committee on the Ethics of Animal Experiments of the UFRN (CEUA, Permit Number: 001/2015).

\section{Mice}

Male Swiss mice, $8-10$ weeks old $(40 \pm 2.0 \mathrm{~g})$ obtained from the UFRN Vivarium Center of Biosciences were maintained under standard conditions (e.g. $12 \mathrm{~h}$ light/ dark cycle, $22 \pm 0.1{ }^{\circ} \mathrm{C}$, and $50-55 \%$ humidity) with species appropriately fed and with water provided ad libitum. The animals were acclimated and subjected to a $12 \mathrm{~h}$ fasting and water ad libitum prior to the experiments. Euthanasia was performed with a subcutaneous administration of $90 \mathrm{mg} / \mathrm{kg}$ sodium thiopental $(0.5 \%$, Tiopentax, Cristália, São Paulo, Brazil).

\section{The carrageenan-induced peritonitis model}

Mice were randomly distributed into twelve groups $(n=5 /$ group). In order to evaluate the effect of $\mathrm{CE}$ and fractions on leukocyte recruitment into the peritoneal cavity, the mice were orally pre-treated with a vehicle (0.9\% saline solution)/carrageenan group, CE or Fractions $(50,100$ and $200 \mathrm{mg} / \mathrm{kg}$ ), or Diclofenac $(10 \mathrm{mg} /$ $\mathrm{kg}$ ). After $30 \mathrm{~min}, 0.25 \mathrm{ml}$ of a $1 \%$ carrageenan solution (Sigma-Aldrich, São Paulo, Brazil) was intraperitoneally (i.p.) injected. The sham group received a vehicle $(1 \mathrm{~mL}$ water $/ 10 \mathrm{~g}$, p.o) and a $0.9 \%$ sterile saline solution intraperitoneal injection $(0.1 \mathrm{~mL} / 10 \mathrm{~g})$ [11]. Then, the mice were euthanized $4 \mathrm{~h}$ later with an overdose of $90 \mathrm{mg} / \mathrm{kg}$ sodium thiopental. Three $\mathrm{mL}$ of saline solution was then injected into each abdominal cavity and peritoneal fluid was collected and diluted (1:20) in Turk's solution. A total leukocyte count was performed for each sample with a Neubauer counting chamber. The samples were stored at $-80^{\circ} \mathrm{C}$ for subsequent analyses of myeloperoxidase (MPO) activity, as well as malondialdehyde (MDA) and total glutathione levels.

\section{Determination of myeloperoxidase activity}

MPO activity was measured according to the technique described by Krawisz et al. [12]. An aliquot $(100 \mu \mathrm{L})$ of each sample was diluted in $2 \mathrm{~mL}$ of hexadecyltrimethylammonium bromide buffer (HTAB, Sigma Aldrich, São Paulo, Brazil) and homogenized. The samples were sonicated for 5 min before being centrifuged at 10,000 rpm for $15 \mathrm{~min}$ at $4{ }^{\circ} \mathrm{C}$, and then subjected to a triple freezethaw process. Biochemical measurements were made of duplicate samples. Next, $7 \mu \mathrm{L}$ of HTAB buffer was added to the blank and supernatant samples in 96-well plates. Then, $200 \mu \mathrm{l}$ of the staining reagent (o-dianisidine 
dihydrochloride) was added to each well and absorbance values at $450 \mathrm{~nm}$ were recorded by Spectrocopical UV/ VIS analysis (Biotek, São Paulo, Brazil). MPO enzyme activity was calculated based on interpolation from a standard curve that was generated from MPO from human neutrophils and horseradish peroxidase. A unit of MPO (U) was defined to degrade $1 \mathrm{nmol} / \mathrm{min}$ of hydrogen peroxide at $25{ }^{\circ} \mathrm{C}$. Therefore, the results obtained in the assays were expressed as $\mathrm{U} / \mu \mathrm{L}$ of sample.

\section{Determination of total glutathione content}

According to the method described by [13], $100 \mu \mathrm{L}$ of each inflammatory lavage was diluted in a $5 \%$ trichloroacetic acid (TCA)/distilled water solution and then homogenized and centrifuged at $10,000 \mathrm{rpm}$ for $15 \mathrm{~min}$ at $4{ }^{\circ} \mathrm{C}$. Each standard dilution $(20 \mu \mathrm{L})$, TCA solution $(20 \mu \mathrm{L}$, Vetec, São Paulo, Brazil) for the blank, and each sample supernatant $(20 \mu \mathrm{L})$ were added to 96-well plates in duplicate. In addition, $15 \mu \mathrm{L}$ PBS-EDTA, $20 \mu \mathrm{L}$ dithiobisnitrobenzoic acid (DTNB) solution, and $140 \mu \mathrm{L}$ NADPH were added to each well. After an incubation step at $30{ }^{\circ} \mathrm{C}$ for $5 \mathrm{~min}$, $15 \mu \mathrm{L}$ of an enzyme solution and GSH reductase (Sigma Aldrish, São Paulo, Brazil) were added to each well. Absorbance values at $412 \mathrm{~nm}$ were recorded by Spectrocopical UV/VIS analysis (Biotek) for $3 \mathrm{~min}$. Total glutathione content was calculated based on interpolations from a standard curve that was generated with purified glutathione ( $\gamma$-L-Glutamyl-L-cysteinyl-glycine, GSH, Sigma Aldrish, São Paulo Brazil, G4251). The results of these assays are expressed in $\mathrm{nmol} / \mu \mathrm{L}$ of sample.

\section{Determination of MDA content}

In order to assess lipid peroxidation, MDA production was measured according to [14]. First, $50 \mu \mathrm{l}$ of each sample was diluted in $250 \mu \mathrm{L}$ of $20 \mathrm{mM}$ Tris $\mathrm{HCl}$ buffer (Trizma hydrochloride, Sigma Aldrich, São Paulo, Brazil) in distilled water $(20 \mathrm{mM}, \mathrm{pH} 7.4)$. The peritoneal fluid samples were homogenized and centrifuged at 10,000 rpm for $10 \mathrm{~min}$ at $4{ }^{\circ} \mathrm{C}$. Then, $750 \mu \mathrm{L}$ of a chromogenic reagent (10.3 mM 1-methyl-2-phenylindole in 3:1 acetonitrile) and $225 \mu \mathrm{L} \mathrm{HCl}$ (37\%) were added to each sample. After an incubation step in a water bath for $40 \mathrm{~min}$ at $45^{\circ} \mathrm{C}$, the samples were centrifuged at $10,000 \mathrm{rpm}$ for $5 \mathrm{~min}$ at $4{ }^{\circ} \mathrm{C}$. Absorbance values at $586 \mathrm{~nm}$ were recorded with a spectroscopic UV/VIS analysis (Biotek, São Paulo, Brazil) and the results were interpolated from a standard curve that was established with 1,1,3,3-tetraethoxypropane (a compound which is hydrolyzed to form MDA when it is incubated with $\mathrm{HCl}$ at $45{ }^{\circ} \mathrm{C}$ ). The results from these assays are expressed as $\mathrm{nmol} / \mu \mathrm{l}$ of sample.

\section{IL-1 $\beta$ and TNF- $\alpha$ assay}

Peritoneal fluid (C-carrageenan, D-diclofenac, CE-crude extract, AqF-aqueous fraction, and EAF-ethyl acetate- treated fraction) was stored at $-70{ }^{\circ} \mathrm{C}$ after extraction, homogenized and processed as described elsewhere [15]. Levels of IL-1 $\beta$ (detection range: $62.5-4000 \mathrm{pg} / \mathrm{mL}$; lower limit of detection: $12.5 \mathrm{ng} / \mathrm{mL}$ recombinant mouse IL-1 $\beta$ ), and TNF- $\alpha$ (detection range: $62.5-4000 \mathrm{pg} / \mathrm{mL}$; lower limit of detection: $50 \mathrm{ng} / \mathrm{mL}$ recombinant mouse TNF- $\alpha$ ) were determined using commercial ELISA kits (R\&D Systems, Minneapolis, MN, USA), as previously described [16].

First, microtiter plates were coated overnight at $4{ }^{\circ} \mathrm{C}$ with antibodies against mouse TNF- $\alpha$ and IL- $1 \beta$. After the plates were blocked, samples and standards were added at various dilutions in duplicate and incubated at $4{ }^{\circ} \mathrm{C}$ for $24 \mathrm{~h}$. The plates were washed 3 times with buffer and antibodies were then added to the wells (biotinylated sheep polyclonal anti-TNF- $\alpha$, anti-IL-1 $\beta$, diluted 1:1000 with $1 \%$ BSA assay buffer). Plates were incubated at room temperature for $1 \mathrm{~h}$, washed, and $50 \mu \mathrm{L}$ of avidin-HRP (1:5000) was added. The color reagent ophenylenediamine $(50 \mu \mathrm{L})$ was added 15 min later, and the plates were incubated in the dark at $37{ }^{\circ} \mathrm{C}$ for $15-$ 20 min. The enzyme reaction was stopped with $\mathrm{H}_{2} \mathrm{SO}_{4}$ and absorbance was measured at $490 \mathrm{~nm}$. Values were expressed in $\mathrm{pg} / \mathrm{ml}$.

\section{Evaluation of antinociceptive activity Hot plate testing}

The Hot plate test was used for measuring central analgesic activity and pain was induced by heat [17]. Mice were randomly distributed into eleven groups $(n=5 /$ group) and they received: $10 \mathrm{~mL} / \mathrm{kg}$ saline solution (Normal control group/No treatment), morphine $(10 \mathrm{mg} / \mathrm{kg}$, ip), and $\mathrm{CE}$, the AqF or the EAF; with the CE and fractions groups receiving oral doses of $50 \mathrm{mg} / \mathrm{kg}, 100 \mathrm{mg} /$ $\mathrm{kg}$, and $200 \mathrm{mg} / \mathrm{kg}$ of their treatment. Each mouse was then placed on a hot plate (Insight, São Paulo, Brazil) maintained at $55 \pm 0.5{ }^{\circ} \mathrm{C}$. The time taken by the animals to jump or lick one of their hind paws was recorded. Latencies were recorded at intervals of $30 \mathrm{~min}, 60 \mathrm{~min}, 90 \mathrm{~min}$, and 120 min after administration of the substances.

\section{Acetic acid-induced abdominal writhing test}

Pain was induced by acetic acid for measuring peripheral analgesic activity [18]. Mice were randomly distributed into eleven groups ( $n=5$ /group). Two groups were treated with $10 \mathrm{~mL} / \mathrm{kg}$ oral saline solution (normal control and acetic acid control). One group was treated with oral indomethacin $(10 \mathrm{mg} / \mathrm{kg})$. The remaining nine groups were treated with oral doses of $\mathrm{CE}(50,100$, or $200 \mathrm{mg} / \mathrm{kg}$ ), AqF (50, 100, or $200 \mathrm{mg} / \mathrm{kg}$ ), or EAF (50, 100 , or $200 \mathrm{mg} / \mathrm{kg}$ ). Nociception was stimulated with an i.p. injection of acetic acid $(0.6 \% v / v)$ diluted in ultrapure water, $30 \mathrm{~min}$ after treating the animals with the $\mathrm{CE}$ and fractions, indomethacin and acetic acid control. The 
normal control received an i.p. injection of saline $10 \mathrm{~mL} / \mathrm{kg}$. After the injection of acetic acid or saline, the mice were placed under inverted glass funnels and the number of writhes that were observed over a period of 20 min was recorded.

\section{Experimental outcomes}

The behavior and deaths of animals were recorded during the experiment.

\section{Statistical analyses}

Data from the control group were treated as baseline values. All experimental data were recorded as the mean \pm standard error of the mean (SEM). The results were statistically evaluated using one-way analysis of variance (ANOVA), followed by Bonferroni's post-hoc test. The level of statistical significance was $p<0.05$. Results analysis and graph generation were performed by using GraphPadPrism version 5.04.

\section{Results}

\section{Chromatographic analyses of the CE and fractions of $E$.} uniflora

Chromatographic analyses were preformed using HPLC. Gallic acid and ellagic acid (monomers of hydrolyzable tannins) and the flavonoid myricitrin were detected in the $\mathrm{CE}$ and fractions of E. uniflora Linn leaves. The retention times (RT) for gallic acid, myricitrin and ellagic acid in these samples were $8.7 \mathrm{~min}$ (Fig. 1a), $23.3 \mathrm{~min}$ (Fig. 1b), and $25.1 \mathrm{~min}$ (Fig. 1c), respectively. The identities of standards in the samples were confirmed by correlating their RTs. Thus, the peeks corresponding to the standards were determinate in the samples from leaves of E. uniflora, as follow: CE (peaks: 1, 2 and 3; Fig. 1d), AqF (peak: 1; Fig. 1e), and EAF (peaks: 1, 2 and 3; Fig. 1f).

Gallic acid, myricitrin and ellagic acid contents in the $\mathrm{CE}$ and fractions were also determined in triplicate by using calibration curves of standards $(y=1.3038 x+$ $0.6907 ; R^{2}=0.9920 ; y=1.4816 x-2.200 ; R^{2}=0.9916 ; y=$ $3.0007 x+3.9969 ; R^{2}=0.9906$, respectively for gallic acid, myricitrin and ellagic acid). These values are summarized in Table 1.

\section{In vitro activities}

\section{Antibacterial activity}

In the performed antibacterial assays, the $\mathrm{CE}$ and fractions of E. uniflora Linn inhibited most of the tested bacteria, except MRSA which was not susceptible to the $\mathrm{CE}$ at $2.5 \mu \mathrm{g} / \mathrm{mL}$, or Escherichia coli which was not susceptible to any of the tested samples (Table 2). In general, the CE had lower MIC values than the fractions, including the lowest MIC against the Staphylococcus epidermidis strain. Normal bacterial growth was observed in all growth (MHA + innoculum) and solvent controls (MHA containing 5\% DMSO). No growth was observed in sterility controls (MHA).

\section{In vivo activities}

All animals presented a perfect state of health and they were included in the experiments. 100\% randomised animals of experimental model were included in carrageenan-induced peritonitis model, Hot plate testing and Acetic acid-induced abdominal writhing test. No animals were excluded from the study. No adverse effects were found.

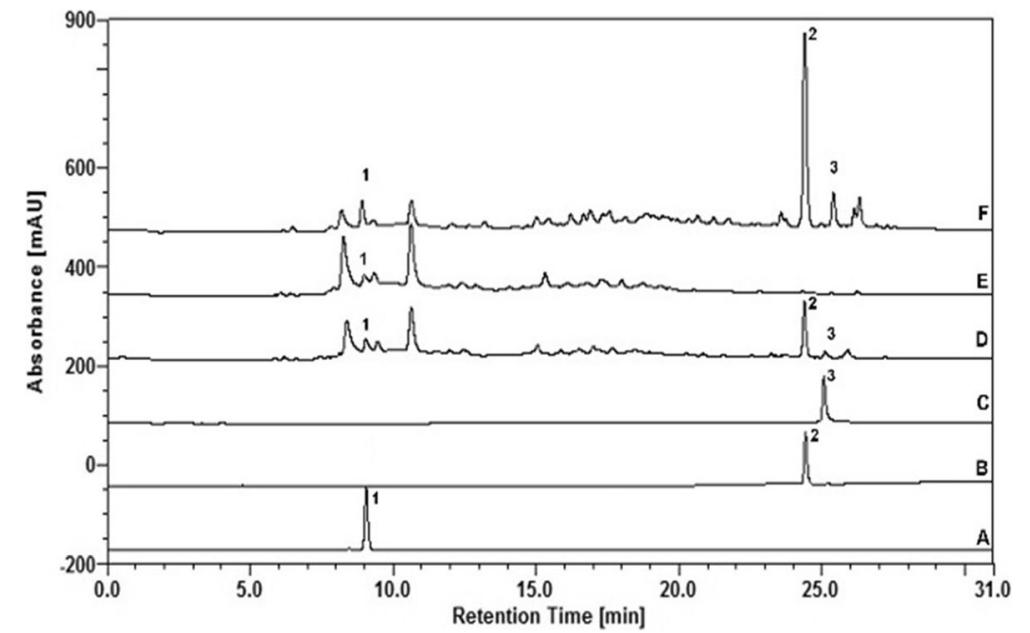

Fig. 1 Chromatographic profiles of Gallic acid (A), Myricitrin (B), Ellagic acid (C), CE (D), AqF (E), and EAF (F) of E. uniflora Linn leaves as determined by HPLC. CE: crude extract, AqF: aqueous fraction, EAF: ethyl acetate-treated fraction. The retention times (RT) for gallic acid, myricitrin and ellagic acid of these substances were $8.7 \mathrm{~min}$ (peak 1), $23.3 \mathrm{~min}$ (peak 2), and $25.1 \mathrm{~min}$ (peak 3) 
Table 1 Content of the chemical markers assayed in the CE and fractions of $E$. uniflora leaves as determined by HPLC-DAD

\begin{tabular}{llll}
\hline Samples & Gallic acid $(\%, w / w)$ & Ellagic acid $(\%, w / w)$ & Myricitrin $(\%, w / w)$ \\
\hline CE & $0.459(1.99)$ & $0.200(2.72)$ & $1.713(0.41)$ \\
AqF & $0.328(3.01)$ & $0.035(3.90)$ & $0.061(5.15)$ \\
EAF & $0.872(0.84)$ & $0.323(4.05)$ & $6.560(0.22)$ \\
\hline
\end{tabular}

Data presented are the mean (relative standard deviation) of three independent measurements

$C E$ crude extract, $A q F$ aqueous fraction, $E A F$ ethyl acetate-treated fraction

\section{Leukocyte migration}

In the leukocyte migration assays, treatment with the $\mathrm{CE}, \mathrm{AqF}$ and EAF at all doses resulted in a significant inhibition of leukocyte migration versus carrageenan group $(p<0.001$ or $p<0.01$, Fig. 2$)$.

\section{MPO activity}

Leukocyte infiltration was assessed with the detection of MPO levels in peritoneal fluid. As shown in Fig. 3, the level of MPO in the positive control group was more than twelve-fold higher $(65 \mathrm{U} / \mu \mathrm{L})$ than the negative control group/saline $(5 \mathrm{U} / \mathrm{ml})(P<0.001)$. Following treatment with diclofenac, a significant reduction in MPO levels was observed compared to the positive control group $(P<0.001)$. Significant reductions in the levels of MPO activity at all doses were observed following treatment with the $\mathrm{CE}, \mathrm{AqF}$ and $\mathrm{EAF}$ as a consequence of the number of neutrophils.

\section{Total glutathione content}

Total glutathione levels were determined in peritoneal fluid samples in order to evaluate the effect of the CE and fractions of E. uniflora Linn on redox homeostasis. In the positive control group, the total glutathione levels decreased approximately 8-fold compared to the negative control group. In contrast, administration of the CE and fractions at doses of $50 \mathrm{mg} / \mathrm{kg}, 100 \mathrm{mg} / \mathrm{kg}$, and $200 \mathrm{mg} / \mathrm{kg}$ all increased the total glutathione levels by
$84 \%$ relative to the positive control group $(P<0.001)$ (Fig. 4). These results suggest that the CE and fractions of E. uniflora Linn mediate antioxidant-related activities.

\section{MDA content}

MDA is one of the main secondary products of lipid peroxidation and is a widely used biomarker to evaluate oxidative stress. MDA is a dialdehyde that is a byproduct of the oxidation of polyunsaturated fatty acids by betacleavage of peroxidase and mainly arachidonic acid. As shown in Fig. 5, MDA levels were higher in the positive control group compared to the treated and negative control groups. However, the $\mathrm{CE}$ and fractions at all doses were able to significantly reduce MDA levels $(p<0.001)$, thereby indicating that a protective effect on lipid peroxidation is mediated by E. uniflora Linn leaves.

\section{Effect of CE and fractions of $E$. uniflora Linn on cytocines IL- $1 \beta$ and TNF- $\alpha$}

The groups subjected to $\mathrm{CE}$ and fractions of $E$. uniflora Linn showed decreased levels of proinflammatory cytokine IL-1 $\beta$ (Diclofenac, CE and fractions of $E$. uniflora CE for all doses, $p<0.001$, except EAF at $200 \mathrm{mg} / \mathrm{kg}, p<0.01$ ) and TNF- $\alpha$ (Diclofenac, $p<0.01$, and AgF, all doses, $p<$ $0.05)$ compared to carrageenan control (Fig. 6).

\section{Evaluation of antinociceptive activity}

In the hot plate test, the morphine-treated group exhibited central analgesic action at all time intervals; however, only the dose of the $200 \mathrm{mg} / \mathrm{kg}$ AqF-treated group exhibited central analgesic action at the 90 min interval. The AqF-treated group does not have a dose-dependent profile, and therefore this may not be due to pharmaceutical activity of AqF. None of the other groups at the other time intervals exhibited significant central analgesic action (Table 3).

In the acetic acid induced abdominal writhing assays, administration of the saline in normal control,

Table 2 MIC of the CE and fractions of E. uniflora Linn against gram-positive and gram-negative bacteria

\begin{tabular}{|c|c|c|c|c|c|c|}
\hline \multirow[t]{2}{*}{ Bacteria } & \multicolumn{6}{|c|}{ Samples MIC $(\mu \mathrm{g} / \mathrm{mL})^{\mathrm{a}}$} \\
\hline & CE & EAF & $\mathrm{AqF}$ & Cephalothin & Gentamicin & Vancomycin \\
\hline \multicolumn{7}{|l|}{ Gram-positive } \\
\hline Staphylococcus aureus ATCC 25923 & $1.250 \pm 0$ & $2.500 \pm 0$ & $2.500 \pm 0$ & $0.5 \pm 0$ & ND & ND \\
\hline Staphylococcus epidermidis INCQS 00016 & $0.313 \pm 0$ & $0.938 \pm 0.44$ & $0.625 \pm 0$ & $0.25 \pm 0$ & ND & ND \\
\hline Enterococcus faecalis ATCC 29212 & $1.250 \pm 0$ & $2.500 \pm 0$ & $2.500 \pm 0$ & $8.0 \pm 0$ & ND & ND \\
\hline MRSA & $\mathrm{NI}$ & $2.500 \pm 0$ & $2.500 \pm 0$ & ND & ND & $2.0 \pm 0$ \\
\hline \multicolumn{7}{|l|}{ Gram-negative } \\
\hline Escherichia coli ATCC 25922 & $\mathrm{NI}$ & $\mathrm{NI}$ & $\mathrm{NI}$ & ND & $0.5 \pm 0$ & ND \\
\hline Salmonella enteretidis INCQS 00258 & $1.250 \pm 0$ & $2.500 \pm 0$ & $2.500 \pm 0$ & ND & $0.125 \pm 0$ & ND \\
\hline Pseudomonas aeruginosa ATCC 27853 & $1.250 \pm 0$ & $1.875 \pm 0.88$ & $2.500 \pm 0$ & ND & $0.5 \pm 0$ & ND \\
\hline
\end{tabular}

$\mathrm{NI}=$ no inhibition; $\mathrm{ND}=$ not determined

a Values are the mean seven standard deviation of two replicates 


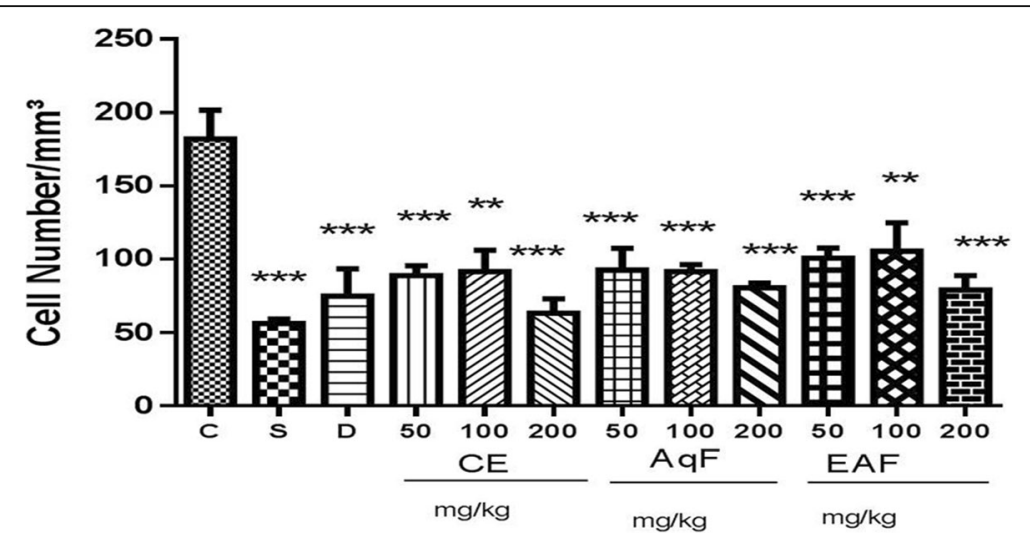

Fig. 2 Effects of the CE and fractions of E. uniflora Linn at various doses on leukocyte migration in a carrageenan-induced peritonitis model versus the carrageenan group. The results are expressed as the mean \pm standard error $(n=5)$. ANOVA test was used to calculate statistical significance. ${ }^{* *} p<0.01,{ }^{* * *} p<0.001$ versus the carrageenan group (C). S (Sham), C (carrageenan), D (diclofenac), CE (crude extract), AqF (aqueous fraction), EAF (ethyl acetate-treated fraction)

Indomethacin, $\mathrm{CE}, \mathrm{AqF}$ and $\mathrm{EAF}$ of E. uniflora Linn resulted in a significant reduction in the number of abdominal writhes compared to the Acetic Acid control ( $p$ $<0.001$, Fig. 7). Acetic acid showed statistically significant differences, and were also observed for the normal control $(p<0.001$, Fig. 7).

\section{Experimental outcomes}

No records of behavior change or death were found during the animal experiment models.

\section{Discussion}

The results obtained in the present study establish a scientific basis for the use of E. uniflora in folk/traditional medicine. For both in vitro and in vivo tests, the $C E$ and fractions from E. uniflora Linn leaves exhibited action on cell viability, antibacterial, anti-inflammatory, and antinociceptive activities.

Myricitrin is the rhamnose glycoside derivative of myricetin, a naturally occurring flavonol that has been extracted from the fruit, bark or leaves of plants. Additionally, myricitrin could also be deglycosylated to the aglycon myricetin [19].

Myricitrin has exhibited several biological functions that represent potential health benefits, including antimutagenic [20], antioxidant [21, 22], anti-inflammatory [22-24] and antinociceptive [25] activities in experimental models. Myricitrin has also been found to protect against skin cancer by strongly inhibiting tumour promoting-induced neoplastic cell transformation via restriction of MEK, JAK1, Akt, and MKK4 kinase activity [26]. Furthermore, myricitrin has been shown to

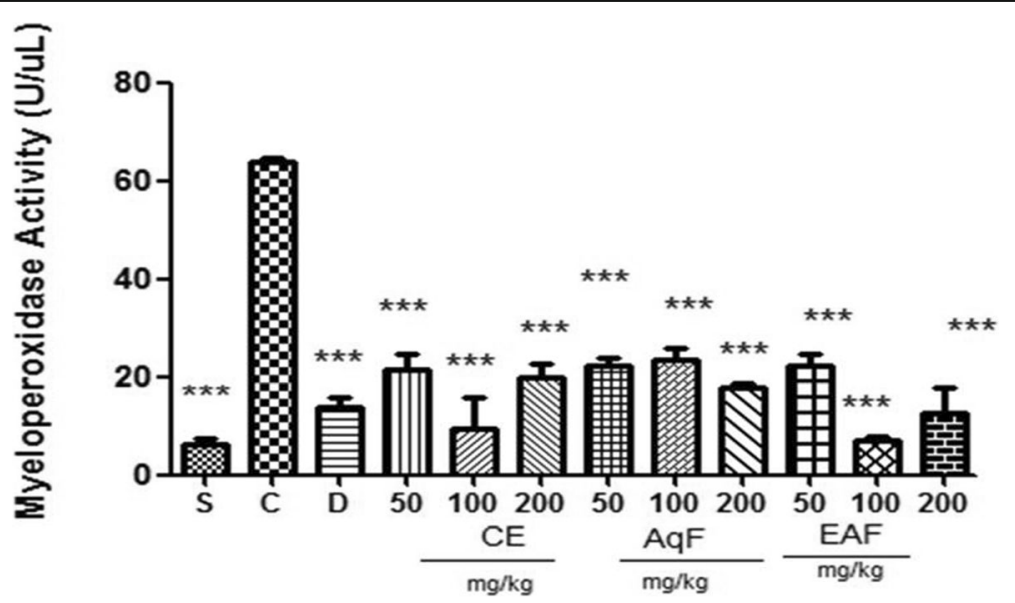

Fig. 3 Effect of the CE and fractions (50, 100 or $200 \mathrm{mg} / \mathrm{kg}$ ) of E. uniflora Linn on MPO activity in a carrageenan induced peritonitis model versus the carrageenan group. Data are expressed as the mean \pm standard mean error $(n=5)$. An ANOVA test was used to calculate statistical significance, ${ }^{* * *} p<0.001$ versus the positive control group. S (Sham), C (carrageenan), D (diclofenac), CE (crude extract), AqF (aqueous fraction), EAF (ethyl acetate-treated fraction) 


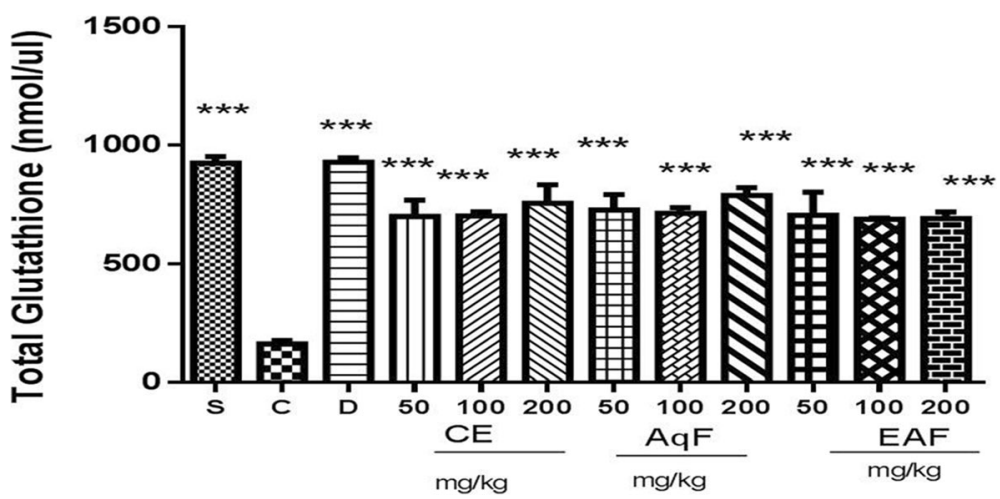

Fig. 4 Effects of the CE and fractions (50, 100 or $200 \mathrm{mg} / \mathrm{kg}$ ) of E. uniflora Linn on total glutathione levels (nmol/ul) in a carrageenan-induced peritonitis model versus the carrageenan group. The results are expressed as the mean \pm standard mean error $(n=5)$. An ANOVA test was used to calculate statistical significance, ${ }^{* * *} p<0.001$ versus the positive control group. S (sham), C (carrageenan), D (diclofenac), CE (crude extract), AqF (aqueous fraction), EAF (ethyl acetate-treated fraction)

attenuate tumour promoting-induced activation of c-fos and activator protein-1 [27], and to inhibit JAK1/STAT3 pathways [28].

In a study by Fiuza et al. (2008), a hydroethanolic extract from E. uniflora Linn leaves was subjected to the agar dilution method, and was found to inhibit the growth of Pseudomonas aeruginosa strains. However, the associated MIC values 2.18 [29], 4.37 [30], 8.75 [30] and $17.50 \mathrm{mg} / \mathrm{ml}$ [29] were approximately 2-7 times higher than the concentrations reported in the present study [31]. In another study which determined MIC values for an E. uniflora Linn hydroethanolic extract using the broth microdilution method, the extract was found to inhibit the growth of $P$. aeruginosa, albeit at a lower concentration $(10 \mu \mathrm{g} / \mathrm{ml})$. In addition, the latter extract did not inhibit a $S$. aureus reference strain [32], being in contrast with the present results. Other studies have reported inhibition of $S$. aureus strains, including the reference strain ATCC 25923, with lower MIC values than those reported herein. Inhibition of $E$. coli strains, including E. coli ATCC 25922, have also been reported, yet this was not observed in the present study [33, 34]. A similar MIC against $S$. aureus strains, including ATCC 25923, was reported in only one other study, with a MIC of $2.187 \mathrm{mg} / \mathrm{ml}$ reported for a hydroethanolic extract with the agar dilution method [35]. These discrepancies may be due to the chemical complexity of the examined samples, especially since the composition of secondary metabolites in vegetal species is dynamic in response to numerous variables related to pre-harvest (harvest site,

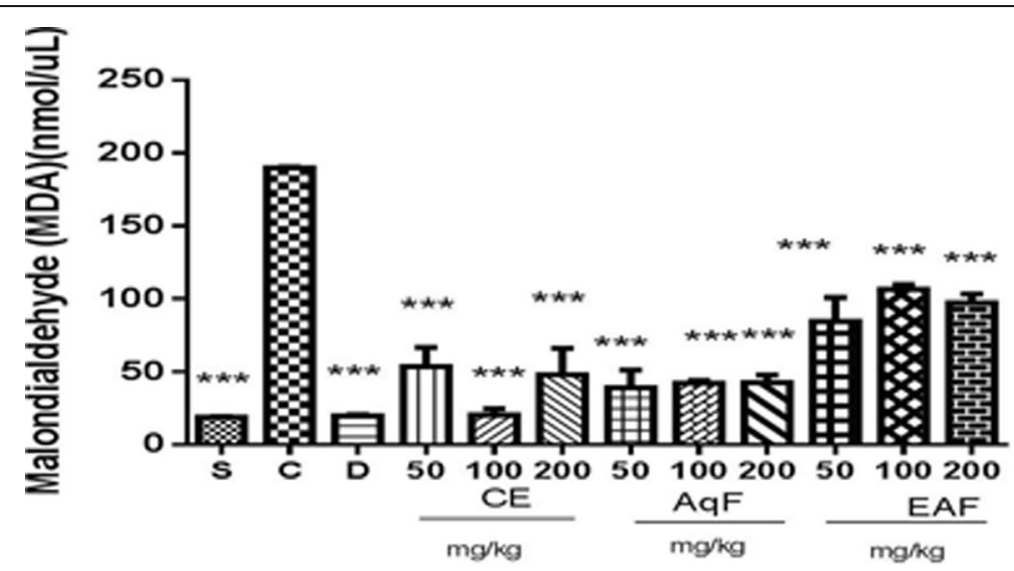

Fig. 5 The effects of the CE and fractions (50, 100 or $200 \mathrm{mg} / \mathrm{kg}$ ) of E. uniflora Linn on MDA levels in a carrageenan-induced peritonitis model versus the carrageenan group. S (sham), C (carrageenan), D (diclofenac), CE (crude extract), AqF (aqueous fraction) and EAF (ethyl acetate-treated fraction). Data are expressed as the mean \pm standard mean error $(n=5)$. An ANOVA test was used to calculate statistical significance, $\left.{ }^{*} p<0.05\right)$, ${ }^{* * *} p<0.001$ versus the positive control group. \#indicates a significant difference between the groups treated with extracts 


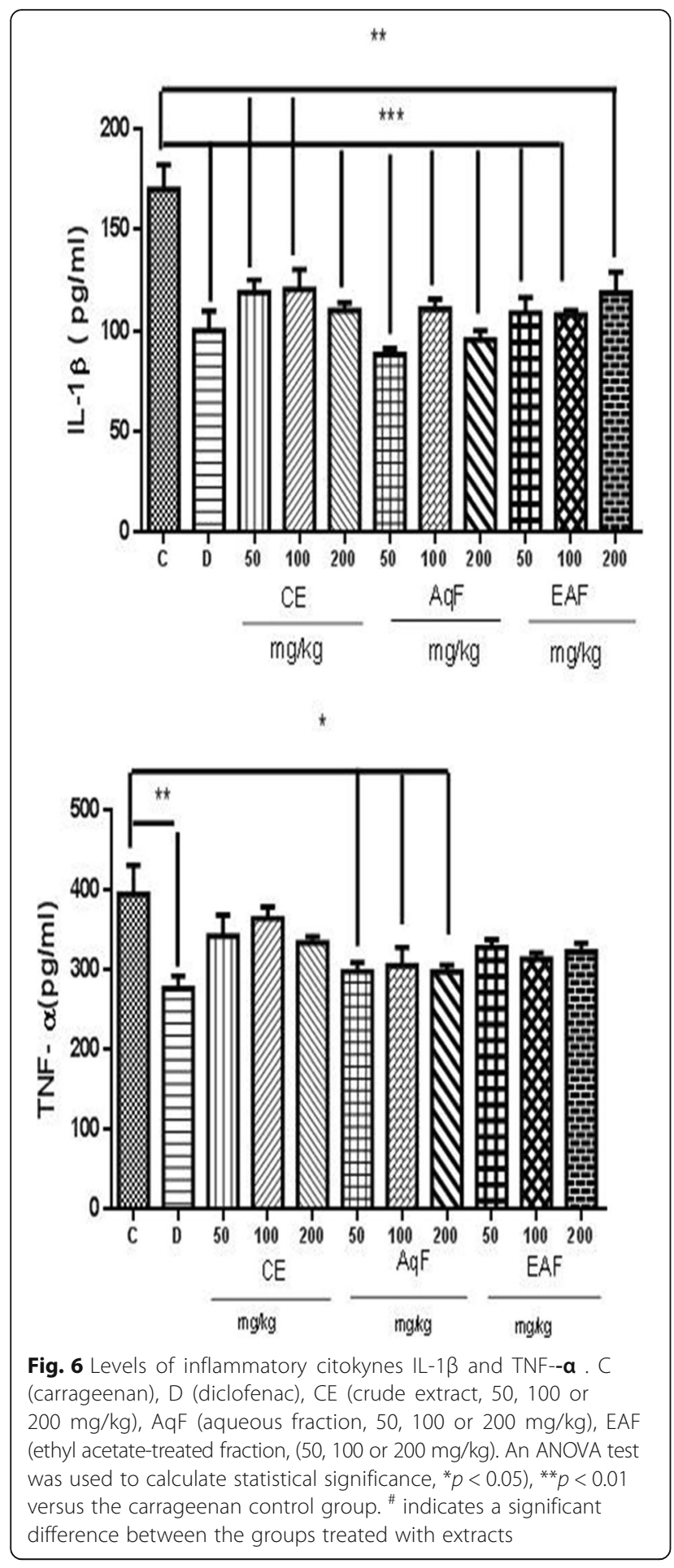

time, altitude, weather) and post-harvest (preservation method of plant material, extraction method, type of extraction liquid) conditions.

In the performed HPLC analyses, the EAF had higher ellagic acid, gallic acid, and myricitrin content. These results suggest that the EAF had higher phenolic compound content in general, including hydrolysable gallotannins, ellagitanins, and flavonoids. It was previously demonstrated that polyphenols, including gallic acid, ellagic acid, tannins, and flavonoids exhibit antibacterial activity against many bacterial strains [36, 37]. Therefore, we hypothesized that the EAF would be more active due to its higher ellagic acid, gallic acid, and myricitrin content. Despite a previous report that an EAF containing flavonoids and tannins was more active than the extract [35], the CE examined in the present study had a lower MIC value than the other prepared fractions. Thus, it is possible that the antibacterial activity observed for the $\mathrm{CE}$ examined herein is due to a synergistic effect of the multiple substances which may have been absent after the fractionation procedure.

Oxidative stress is an event that characterizes many human disorders, including inflammation and cancer. Oxidative stress can result from an imbalance between levels of reactive oxygen species (ROS) and antioxidants that are responsible for cellular defense (e.g. glutathione, superoxide dismutase). In the inflammatory process, oxidative stress is mediated by phagocytes containing MPO, and these result in an overproduction of ROS which overcomes oxidative defense, such as the presence of GSH, a tripeptide normally involved in the prevention of oxidative damage in tissues. Thus, the ability of GSH to maintain a reduced intracellular environment makes it an important antioxidant activity marker.

The beneficial effect of the CE and fractions of E. uniflora Linn in the inflammatory process were confirmed based on the observed reduced leukocyte migration. As an important marker of neutrophil migration, MPO activity was also reduced following treatment. The protective effect of the $\mathrm{CE}$ on oxidative stress was demonstrated by its ability to prevent the reduction of total glutathione levels and MDA (a marker of lipid peroxidation). The anti-inflammatory capacity of the flavonoid myricitrin was previously demonstrated based on its inhibition of prostaglandin production induced by lipopolysaccharide (LPS) [28]. Myricitrin was also found to inhibit the production of LPS-stimulated nitric oxide, pro-inflammatory cytokines, prostaglandin E2 production, and protein levels of inducible nitric oxide synthase and cyclooxygenase- 2 in RAW 264.7 macrophage [23].

In the abdominal writhing model, all extracts at all doses exhibited evident peripheral antinociceptive activity, demonstrating that the decrease in the inflammatory process was accompanied by an evident decrease in pain at the peripheral level. The nociceptive mechanism caused by acetic acid involves different mechanisms such as a release of arachidonic acid metabolites via cyclooxygenase and biosynthesis of prostaglandins and histamines, among others [38]. In the last decade, it has been shown that inflammatory stimuli do not directly 
Table 3 Evaluation of the analgesic activity of E. uniflora CE and fractions at various doses

\begin{tabular}{|c|c|c|c|c|c|}
\hline \multirow[t]{2}{*}{ Administered treatment } & \multirow{2}{*}{$\begin{array}{l}\text { Initial pain latency } \\
\text { os }\end{array}$} & \multicolumn{4}{|c|}{ Pain latency at the indicated time points after administration } \\
\hline & & $30 \mathrm{~min}$ & $60 \mathrm{~min}$ & $90 \mathrm{~min}$ & $120 \min$ \\
\hline Normal Control/No treatment & $13+5.0$ & $6.2+6.8$ & $4.8+3.3$ & $7.8+5.1$ & $6.3+2.1$ \\
\hline Morphine (10 mg/kg) & $8+2.3$ & $27+3.0^{*}$ & $23+7.8^{*}$ & $25+6.4^{*}$ & $26+2.6^{*}$ \\
\hline \multicolumn{6}{|l|}{ CE } \\
\hline $50 \mathrm{mg} / \mathrm{kg}$ & $7.6+3.2$ & $7.8+4.1$ & $11.8+7.5$ & $12+9.3$ & $8.6+6.2$ \\
\hline $100 \mathrm{mg} / \mathrm{kg}$ & $8.4+2.3$ & $8.4+6.0$ & $18.6+7.4$ & $6.2+6$ & $8.4+4.6$ \\
\hline $200 \mathrm{mg} / \mathrm{kg}$ & $10.6+3.0$ & $8.4+5.0$ & $15.6+11.1$ & $10.8+10.7$ & $12.6+6.3$ \\
\hline \multicolumn{6}{|l|}{$\mathrm{AqF}$} \\
\hline 50 mg/kg & $4.8+3.3$ & $13.2+5.5$ & $9.6+8.1$ & $15.4+12.1$ & $14.2+9.2$ \\
\hline $100 \mathrm{mg} / \mathrm{kg}$ & $5.4+2.4$ & $16.2+5.6$ & $17.2+8.5$ & $9.8+5.5$ & $18.4+8.2$ \\
\hline $200 \mathrm{mg} / \mathrm{kg}$ & $7.6+2.7$ & $17.2+6.8$ & $12+9.7$ & $22.2+4.4^{*}$ & $12.6+4.6$ \\
\hline \multicolumn{6}{|l|}{ EAF } \\
\hline 50 mg/kg & $7.6+2.1$ & $15.2+7.7$ & $8.8+5.5$ & $6+3$ & $10.2+6.5$ \\
\hline $100 \mathrm{mg} / \mathrm{kg}$ & $5.4+2.1$ & $8+1.9$ & $5.8+2.9$ & $5+2.7$ & $3+1.5$ \\
\hline $200 \mathrm{mg} / \mathrm{kg}$ & $6.2+3.5$ & $15.2+2.7$ & $8.8+2.8$ & $6.2+2.9$ & $8.4+2.5$ \\
\hline
\end{tabular}

stimulate the release of primary hypernociceptive mediators, but that their release is preceded by a cascade of cytokines. There is a cascade release of cytokines that constitutes a link between the injuries and the release of primary hypernociceptive mediators [39]. This concept allows us to understand why the inhibition of one (IL-1 $\beta$ or TNF- $\alpha$ ) or several (glucocorticoids) cytokines causes analgesia [39]. Our study was able to show that connection among the $\mathrm{CE}$ and fraction, decreased IL$1 \beta$ and TNF- $\alpha$ levels, and reduced peripheral antinociceptive activity.

On the other hand, the hot plate test consists in evaluating the response of a drug in consequence of a thermogenic stimulus [40]. In this test, the thermal stimulus activates the nociceptors (non-myelinated type
C fibers) that transmit the information to specific regions in the Central Nervous System, thus producing a nociceptive response [41]. This test is effective to determine the analgesic activity of opioid agonists [42]. The response of $\mathrm{CE}$ and fractions in the hot plate test suggested that it did not demonstrate opioid action.

Polyphenolic constituents such as tannins have antioxidant and anti-inflammatory properties. In a previous study of an aqueous extract of E. uniflora Linn, hydrolysable tannins (e.g. gallic acid and ellagic acid) were identified and the extract was applied to an acute diabetic model [8]. The animals that received the extract had a reduced inflammatory infiltrate index, with a decrease in the infiltration of inflammatory cells from $25 \%$ to $80 \%$ observed in the untreated versus treated animals, respectively. The

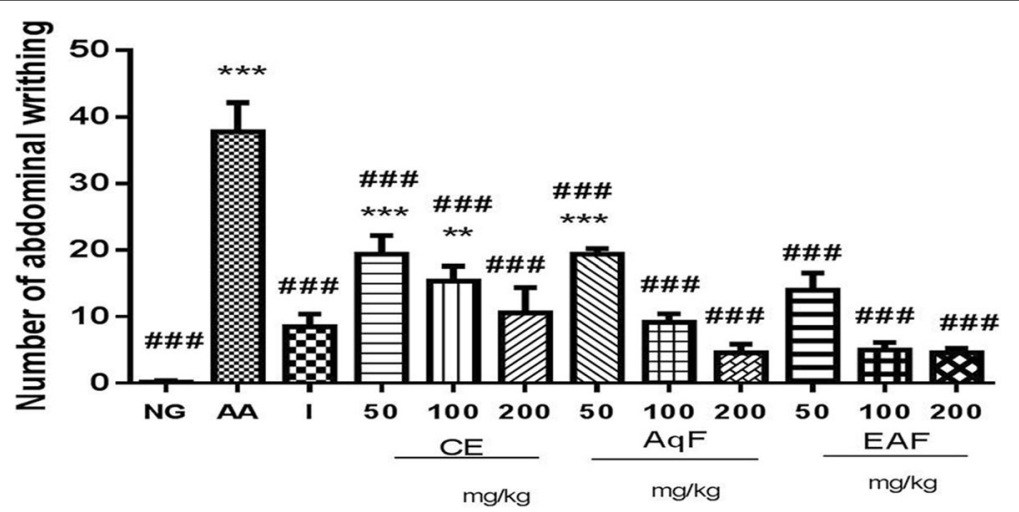

Fig. 7 Antinociceptive effects of the Indomethacin, CE and fractions (50, 100 or $200 \mathrm{mg} / \mathrm{kg}$ ) of E. uniflora Linn at various doses on the number abdominal contortions observed following the administration of acetic acid. Data are expressed as the mean \pm standard mean error $(n=5)$. An test was used to calculate statistical significance, ${ }^{* * *} p<0.001$ versus the normal control; \#\#\#p $<0.001$ versus the Acid Acetic. NG (normal control group), AA (acetic acid), I (indomethacin), CE (crude extract), AqF (aqueous fraction), EAF (ethyl acetate-treated fraction) 
levels of inflammatory cytokines, especially those of TNF$\alpha$, were significantly reduced in the AqF-treated group at all doses, with high ellagic acid and myricitrin content. In macrophages, myricitrin reduced the production of proinflammatory mediators such as NO, iNOS, TNF- $\alpha$, IL-6, and IL-12 through the suppression of NF-kB and STAT1 activation [43]. Ellagic acid pre-treatment decreased the expression of pro-inflammatory cytokines, such as tumour necrosis factor $\alpha$ (TNF- $\alpha$ ), interleukin 6 (IL-6), and interleukin $1 \beta$ (IL-1 $\beta)$. These results suggest that ellagic acid protects against $\mathrm{T}$-cell-mediated hepatitis through TLR and mitogen-activated protein kinase (MAPK)/NF- $\mathrm{KB}$ signaling pathways [44].

This anti-inflammatory effect may be partly explained by a reduction in lipid peroxidation, which would imply that an antioxidant effect is mediated by an intracellular reduction in glutathione consumption. The analgesic effects associated with the $\mathrm{CE}$ and fractions of E. uniflora Linn in the present study are consistent with the antinociceptive activities observed in a study of essential oils that were isolated from E. uniflora Linn leaves and inhibited animal constrictions by $48 \%$ at an oral dose of $200 \mathrm{mg} / \mathrm{kg}$. The pentane fraction of E. uniflora Linn leaves has also been shown to mediate a significant antinociceptive effect which included an inhibition of animal constrictions by $70 \%$ at the same dose [2].

Myricitrin was also previously reported to exert a significant analgesic effect in an acetic acid-induced writhing response assay [45]. In the present study, the $C E$ and the fractions induced a significantly greater analgesic effect. This observation may be related to the myricitrin, gallic acid, and ellagic acid contents that were detected in $C E$ and the fraction of E. uniflora Linn leaves.

\section{Conclusions}

Regarding the antibacterial effects of E. uniflora Linn leaves, a variability of the results reported in the literature in combination with the unexpected findings observed in the present study indicate that further studies are necessary to determine the active antibacterial compound that is present in E. uniflora Linn leaves. These studies may involve an evaluation of antibacterial activity in leaf extracts that are collected from different locations, concurrent with a detailed phytochemical analysis. The goal would be to identify which substances are present or absent in active versus less active extracts. The $\mathrm{CE}$ and semi-purified fractions of $E$. uniflora Linn leaves exhibited antiinflammatory and analgesic activities. The treatment doses also inhibited cell migration, as confirmed in MPO assays and showed anti-inflammatory activity with decreased IL$1 \beta$ levels (CE and all fractions), but AqF (all doses) decreased TNF- $\alpha$ levels. Furthermore, according to the determinations of total glutathione and MDA levels, it is evident that E. uniflora Linn leaf extract can mediate antioxidant activity. The AqF may be related to the greater myricitrin, gallic acid, and ellagic acid contents, and induced a significantly greater analgesic effect relative to the $\mathrm{CE}$ and the fractions.

\section{Abbreviations \\ ANOVA: One-way analysis of variance; AqF: Aqueous Fraction; BAPTA: AM - 1,2- Bis(2-aminophenoxy)ethane-N,N,N',N'-tetraacetic acid tetrakis(acetoxymethyl ester); BHI: Brain Heart Infusion Broth; CE: Crude extract; CEUA: Ethics Committee on Animal Use; DTNB: Dithiobisnitrobenzoic acid; EAF: Ethyl Acetate Fraction; GSH: $\gamma^{-}$ L-Glutamyl-L-cysteinyl-glycine; HPLC-DAD: High-performance liquid chromatography with photodiode array detection; \\ HTAB: Hexadecyltrimethylammonium bromide buffer; i.p.: Intraperitoneal; MDA: Malondialdehyde; MHA: Microbialpolyhydroxyalkanoates; MICs: Minimum inhibitory concentrations; MPO: Myeloperoxidase; MRSA: Methicillin resistant Staphylocuccus aureus; NIH: National Institute health; PVDF: Polyvinylidene fluoride: RT: Retention times; SEM: Standard error of the mean; TCA: Trichloroacetic acid; UFRN: Universidade Federal do Rio Grande do Norte; UV: Ultra violete; VIS: Visible}

\section{Acknowledgements}

We thank to Pro-Reitoria de Pesquisa and Post-graduation program of Pharmaceutical Science/UFRN/Brazil.

\section{Funding}

This work was supported by Fundação de Amparo à Ciência e Tecnologia de Pernambuco/FACEPE (APQ-0493-4.03/14; BIC-0200-4.03/15; IBPG-0557-4.03/

15) and Conselho Nacional de Desenvolvimento Científico e Tecnológico/ CNPq (308386/2015-9).

\section{Availability of data and materials}

Data is available from the corresponding author on reasonable request.

\section{Authors' contributions}

TRF, AAA, GCBG, LALS, RTMR, ICFB, MRAF, MASN, MCNM, RFAJ, ACVAG and JSM: made substantial contributions to conception and design, or acquisition of data, or analysis and interpretation of data; TRF, AAA, GCBG, LALS, MRAF, MASN, MCNM, RFAJ: been involved in drafting the manuscript or revising it critically for important intellectual content; TRF, AAA, GCBG, LALS, RTMR, ICFB, MRAF, MASN, MCNM, RFAJ, ACVAG and JSM: given final approval of the version to be published. Each author should have participated sufficiently in the work to take public responsibility for appropriate portions of the content; and TRF, AAA, GCBG, LALS, RTMR, ICFB, MRAF, MASN, MCNM, RFAJ, ACVAG and JSM: agreed to be accountable for all aspects of the work in ensuring that questions related to the accuracy or integrity of any part of the work are appropriately investigated and resolved.

\section{Ethics approval and consent to participate}

This study was approved by the Ethics Committee on Animal Use/CEUA/ Universidade Federal do Rio Grande do Norte/UFRN, protocol n01/2015) of the Federal University of Rio Grande do Norte, Brazil. The animal care and research protocols employed were based on the principles and guidelines adopted by the Guide for the Care and Use of Laboratory Animals.

Consent for publication

Not applicable.

\section{Competing interests}

The authors declare that they have no competing interests.

\section{Publisher's Note}

Springer Nature remains neutral with regard to jurisdictional claims in published maps and institutional affiliations.

\section{Author details}

'Department of Biophysics and Pharmacology, UFRN, Av. Senador Salgado Filho, S/N, Campus Universitário, Lagoa Nova, Natal, RN 59072-970, Brazil. ${ }^{2}$ Department of Pharmaceutical Sciences, UFPE, Recife, PE, Brazil.

${ }^{3}$ Department of Pharmacy, UFRN, Natal, RN, Brazil. ${ }^{4}$ UFRN, Natal, RN, Brazil.

${ }^{5}$ Department of Morphology, UFRN, Natal, RN, Brazil. 
Received: 24 July 2017 Accepted: 23 February 2018

Published online: 09 March 2018

\section{References}

1. Baptista MM, Ramos MA, de Albuquerque UP, Coelho-de-Souza G, Ritter MR Traditional botanical knowledge of artisanal fishers in southern Brazil. J Ethnobiol Ethnomed. 2013;9:54

2. Amorim AC, Lima CK, Hovell AM, Miranda AL, Rezende CM. Antinociceptive and hypothermic evaluation of the leaf essential oil and isolated terpenoids from Eugenia uniflora L. (Brazilian Pitanga). Phytomedicine. 2009;16(10):923-8.

3. Medeiros MFT, da Fonseca VS, Andreata RHP. Plantas medicinais e seus usos pelos sitiantes da Reserva Rio das Pedras, Mangaratiba, RJ, Brasil. Acta Bot Bras. 2004:18:391-9.

4. Ramalingum N, Mahomoodally MF. The therapeutic potential of medicinal foods. Adv Pharmacol Sci. 2014;2014:354264

5. de Santana BF, Voeks RA, Funch LS. Ethnomedicinal survey of a maroon community in Brazil's Atlantic tropical forest. J Ethnopharmacol. 2016;181:37-49.

6. Brasileiro BG, Pizziolo VR, Raslan DS, Jamal CM, Silveira D. Antimicrobial and cytotoxic activities screening of some Brazilian medicinal plants used in Governador Valadares district. Rev Bras Ciênc Farm. 2006:42:195-202.

7. Rattmann YD, de Souza LM, Malquevicz-Paiva SM, Dartora N, Sassaki GL, Gorin PA, lacomini M. Analysis of Flavonoids from Eugenia uniflora Leaves and Its Protective Effect against Murine Sepsis. Evid Based Complement Alternat Med. 2012:2012:623940.

8. Schumacher NS, Colomeu TC, de Figueiredo D, Carvalho Vde C, Cazarin CB, Prado MA, Meletti LM, Zollner Rde L. Identification and Antioxidant Activity of the Extracts of Eugenia uniflora Leaves. Characterization of the AntiInflammatory Properties of Aqueous Extract on Diabetes Expression in an Experimental Model of Spontaneous Type 1 Diabetes (NOD Mice). Antioxidants (Basel). 2015:4(4):662-80.

9. Teixeira LA, Resende CA, Ormonde LR, Rosenbaum R, Fiqueiredo AM, de Lencastre H, Tomasz A. Geographic spread of epidemic multiresistant Staphylococcus aureus clone in Brazil. J Clin Microbiol. 1995;33(9):2400-4.

10. CLSI CaLSI. Methods for Dilution Antimicrobial Susceptibility Tests for Bacteria That Grow Aerobically; Approved Standard — Ninth Edition. M07A9; 2012. p. 32.

11. Ribeiro RA, Flores CA, Cunha FQ, Ferreira SH. IL-8 causes in vivo neutrophil migration by a cell-dependent mechanism. Immunology. 1991;73(4):472-7.

12. Krawisz JE, Sharon P, Stenson WF. Quantitative Assay for Acute Intestinal Inflammation Based on Myeloperoxidase Activity - Assessment of Inflammation in Rat and Hamster Models. Gastroenterology. 1984;87(6): 1344-50.

13. Anderson ME. Determination of glutathione and glutathione disulfide in biological samples. Methods Enzymol. 1985;113:548-55.

14. Esterbauer $\mathrm{H}$, Cheeseman $\mathrm{KH}$. Determination of aldehydic lipid peroxidation products: malonaldehyde and 4-hydroxynonenal. Methods Enzymol. 1990; 186:407-21.

15. Safieh-Garabedian B, Poole S, Allchorne A, Winter J, Woolf CJ. Contribution of interleukin-1 beta to the inflammation-induced increase in nerve growth factor levels and inflammatory hyperalgesia. Br J Pharmacol. 1995;1 15(7):1265-75.

16. Kendall C, Ionescu-Matiu I, Dreesman GR. Utilization of the biotin/avidin system to amplify the sensitivity of the enzyme-linked immunosorbent assay (ELISA). J Immunol Methods. 1983;56(3):329-39.

17. Kuraishi $Y$, Harada Y, Aratani S, Satoh M, Takagi H. Separate involvement of the spinal noradrenergic and serotonergic systems in morphine analgesia: the differences in mechanical and thermal algesic tests. Brain Res. 1983; 273(2):245-52.

18. Koster R, Anderson M, Debeer EJ. Acetic Acid for Analgesic Screening. Fed Proc. 1959:18(1):412

19. Du LY, Zhao M, Xu J, Qian DW, Jiang S, Shang EX, Guo JM, Liu P, Su SL, Duan JA, et al. Identification of the metabolites of myricitrin produced by human intestinal bacteria in vitro using ultra-performance liquid chromatography/quadrupole time-of-flight mass spectrometry. Expert Opin Drug Metab Toxicol. 2014;10(7):921-31.

20. Edenharder $R$, Grunhage D. Free radical scavenging abilities of flavonoids as mechanism of protection against mutagenicity induced by tert-butyl hydroperoxide or cumene hydroperoxide in Salmonella typhimurium TA102. Mutat Res. 2003;540(1):1-18.

21. Chen W, Feng L, Shen Y, Su H, Li Y, Zhuang J, Zhang L, Zheng X. Myricitrin inhibits acrylamide-mediated cytotoxicity in human Caco-2 cells by preventing oxidative stress. Biomed Res Int. 2013;2013:724183.
22. Domitrovic R, Rashed K, Cvijanovic O, Vladimir-Knezevic S, Skoda M, Visnic A Myricitrin exhibits antioxidant, anti-inflammatory and antifibrotic activity in carbon tetrachloride-intoxicated mice. Chem Biol Interact. 2015;230:21-9.

23. Kim HH, Kim DH, Kim MH, Oh MH, Kim SR, Park KJ, Lee MW. Flavonoid constituents in the leaves of Myrica rubra sieb. et zucc. with antiinflammatory activity. Arch Pharm Res. 2013;36(12):1533-40.

24. Shimosaki S, Tsurunaga $Y$, Itamura $H$, Nakamura M. Anti-allergic effect of the flavonoid myricitrin from Myrica rubra leaf extracts in vitro and in vivo. Nat Prod Res. 2011;25(4):374-80.

25. Meotti FC, Luiz AP, Pizzolatti MG, Kassuya CA, Calixto JB, Santos AR. Analysis of the antinociceptive effect of the flavonoid myricitrin: evidence for a role of the L-arginine-nitric oxide and protein kinase C pathways. J Pharmacol Exp Ther. 2006;316(2):789-96.

26. Semwal DK, Semwal RB, Combrinck S, Viljoen A. Myricetin: A Dietary Molecule with Diverse Biological Activities. Nutrients. 2016:8(2):90.

27. Lee KW, Kang NJ, Rogozin EA, Kim HG, Cho YY, Bode AM, Lee HJ, Surh YJ, Bowden GT, Dong Z. Myricetin is a novel natural inhibitor of neoplastic cell transformation and MEK1. Carcinogenesis. 2007;28(9):1918-27.

28. Ichimatsu D, Nomura M, Nakamura S, Moritani S, Yokogawa K, Kobayashi S, Nishioka T, Miyamoto K. Structure-activity relationship of flavonoids for inhibition of epidermal growth factor-induced transformation of JB6 $\mathrm{Cl} 41$ cells. Mol Carcinog. 2007:46(6):436-45.

29. Hefti A. Relative gnotobiosis: a possibility for studying periodontal diseases in the rat. SSO Schweiz Monatsschr Zahnheilkd. 1979;89(7):689-98.

30. Mori M, Ito N. Animals used as models in dentistry: ODU rats as a model for the study of periodontal diseases. Jikken Dobutsu. 1978;27(2):200-2.

31. S-MS FTS, Paula JR, CarmoFilho JR, Pimenta FC. Antimicrobial Activity of the Crude Ethanol Extract and Fractions from Eugenia uniflora Leaves Against Pseudomonas aeruginosa. Lat Am J Pharm. 2009;28(6):8.

32. Bouzada MLM, Fabri RL, Nogueira M, Konno TUP, Duarte GG, Scio E. Antibacterial, cytotoxic and phytochemical screening of some traditional medicinal plants in Brazil. Pharm Biol. 2009;47(1):44-52.

33. Fadeyit MO, Akpan UE. Antibacterial activities of the leaf extracts of Eugenia uniflora Linn. (Synonym Stenocalyx michelli Linn.) Myrtaceae. Phytother Res. 1989:3(4):154-5.

34. Holetz FB, Pessini GL, Sanches NR, Cortez DA, Nakamura CV, Filho BP. Screening of some plants used in the Brazilian folk medicine for the treatment of infectious diseases. Mem Inst Oswaldo Cruz. 2002;97(7):1027-31.

35. Fiúza TS, Sabóia-Morais SM, Paula JR, Tresvenzol LMF, Pimenta FC. Evaluation of antimicrobial activity of the crude ethanol extract of Eugenia uniflora L. leaves. Rev Ciênc Farm Básica Apl. 2008:29(3):6.

36. Borges A, Ferreira C, Saavedra MJ, Simoes M. Antibacterial activity and mode of action of ferulic and gallic acids against pathogenic bacteria. Microb Drug Resist. 2013:19(4):256-65.

37. Engels C, Schieber A, Ganzle MG. Inhibitory spectra and modes of antimicrobial action of gallotannins from mango kernels (Mangifera indica L.). Appl Environ Microbiol. 2011;77(7):2215-23.

38. Gawade SP. Acetic acid induced painful endogenous infliction in writhing test on mice. J Pharmacol Pharmacother. 2012;3(4):348.

39. Cunha TM, Verri WA Jr, Silva JS, Poole S, Cunha FQ, Ferreira SH. A cascade of cytokines mediates mechanical inflammatory hypernociception in mice. Proc Natl Acad Sci U S A. 2005;102(5):1755-60.

40. Langerman L, Zakowski Ml, Piskoun B, Grant GJ. Hot plate versus tail flick: evaluation of acute tolerance to continuous morphine infusion in the rat model. J Pharmacol Toxicol Methods. 1995;34(1):23-7.

41. Dubin AE, Patapoutian A. Nociceptors: the sensors of the pain pathway. J Clin Invest. 2010;120(11):3760-72.

42. Janicki $P$, Libich J. Detection of antagonist activity for narcotic analgesics in mouse hot-plate test. Pharmacol Biochem Behav. 1979:10(4):623-6.

43. Cho BO, Yin HH, Park SH, Byun EB, Ha HY, Jang SI. Anti-inflammatory activity of myricetin from Diospyros lotus through suppression of NF-kappaB and STAT1 activation and Nrf2-mediated HO-1 induction in lipopolysaccharide-stimulated RAW264.7 macrophages. Biosci Biotechnol Biochem. 2016;80(8):1520-30.

44. Lee JH, Won JH, Choi JM, Cha HH, Jang YJ, Park S, Kim HG, Kim HC, Kim DK. Protective effect of ellagic acid on concanavalin A-induced hepatitis via tolllike receptor and mitogen-activated protein kinase/nuclear factor kappaB signaling pathways. J Agric Food Chem. 2014;62(41):10110-7.

45. Tong Y, Zhou XM, Wang SJ, Yang Y, Cao YL. Analgesic activity of myricetin isolated from Myrica rubra Sieb. et Zucc. leaves. Arch Pharm Res. 2009;32(4): 527-33. 